\title{
Social Workers' Causal Attributions for Poverty: Does the Level of Spatial Concentration of Disadvantages Matter?
}

\author{
Ildikó Husz ${ }^{1,2}$ (D) Marianna Kopasz ${ }^{3}$ (D) Márton Medgyesi ${ }^{1,2}$ (D)
}

Accepted: 17 December 2021 / Published online: 12 January 2022

(c) The Author(s) 2022

\begin{abstract}
Social workers may play an important role in the implementation of welfare policies targeted at the poor. Their norms, beliefs, and attitudes form local anti-poverty programmes and affect discretionary practices with their clients. Despite this, we know little about how social workers' exposure to poverty shapes their attitudes towards poverty and their causal attributions for poverty. This study investigates social workers' poverty explanations and the extent to which they depend on the level of local poverty. Data from a survey conducted among Hungarian social workers were analysed using multilevel linear regression models. To measure local poverty, we used a composite index of poverty, as well as a subjective measure of exposure to poverty. Our analysis revealed that most social workers explained poverty with structural causes, but individual blame was also frequent. Contrary to our hypothesis, the level of local poverty did not significantly increase the adoption of structural explanations but did raise the occurrence of individualistic ones. However, the effect of local poverty was non-linear: social workers tended to blame the poor for their poverty in the poorest municipalities, where multiple disadvantages are concentrated, while moderate poverty did not lead to such opinions. Our results suggest that efforts should be made to improve the poverty indicator framework to better understand the phenomenon of spatial concentration of multiple disadvantages and its consequences for the poor.
\end{abstract}

Keywords Attitudes - Attributions for poverty - Spatial concentration of disadvantages · Post-socialist countries $\cdot$ Social workers $\cdot$ Multilevel linear regression

\section{Introduction}

In post-socialist countries, the most painful side effect of transition from state socialism to market economy was arguably the emergence of a previously unknown level of poverty. Income inequality was low and poverty was barely visible in the pre-transition period,

Márton Medgyesi

medgyesi.marton@tk.hu

1 Child Opportunities Research Group, Centre for Social Sciences, Budapest, PO Box 340, 1476, Hungary

2 Corvinus Institute for Advanced Studies, Corvinus University of Budapest, Budapest, Hungary

3 Institute for Political Science, Centre for Social Sciences, Budapest, Hungary 
as a consequence of egalitarian ideology and near-full employment. Transformation from state-socialism to market economy quickly led to high unemployment and severe income poverty. Although the problems of restructuring have mostly been resolved in each country, their accession to the European Union has raised new questions about poverty in the EU. Despite the convergence, post-socialist countries continue to have far lower median incomes when compared to 'old' EU countries, and many of them face extreme poverty (Bradshaw \& Movshuk, 2019).

We know little about how these rapid structural changes shape people's attitudes towards the poor in post-socialist countries. These attitudes are important 'because they are likely to have significant consequences for poor people themselves, especially in terms of the impact of these attitudes on middle-class voting behavior, willingness to help alleviate or end poverty, and beliefs about welfare and welfare reform' (Cozzarelli et al., 2001: 208).

Attitudes of professionals such as social workers may have a particularly important influence on the poor. As street-level bureaucrats (Lipsky, 1980) in contact with the poor on a daily basis, they 'not only deliver but also actively shape policy outcomes by interpreting rules and allocating scarce resources' (Meyers \& Vorsanger, 2003: 307). Research suggests that social workers' norms, beliefs, and attitudes form local anti-poverty strategies and programmes (Reingold \& Liu, 2008) and play a role in their discretionary practices with their clients (e.g. Keiser, 1999).

A large body of research has focused on attributions for poverty. Comparative research on the lay population has revealed that explanations of poverty depend on the respondents' individual characteristics and the national political, institutional, cultural, and socio-economic contexts in which they live. Few studies have investigated how community-level factors such as local poverty affect beliefs pertaining to the causes of poverty. Some findings show that the more respondents are exposed to homelessness or poverty -in direct or indirect forms - the more likely they are to explain it with external (structural) factors instead of individualistic ones (e.g. Lee et al., 2004; Lepianka, 2007).

There is far less evidence on how social workers' attributions for poverty are influenced by the characteristics of the local contexts in which they carry out their activities. They may be more exposed to poverty than the general population, as they are more often in contact with the poor. However, the literature shows a mixed picture identifying predominantly structural explanations of poverty in Nordic countries (Blomberg et al., 2013) and individualistic ones in Latvia (Landmane \& Reņge, 2010).

This study aims to contribute to filling a research gap by investigating social workers' poverty explanations in a post-socialist country, namely Hungary. More specifically, we assume that social workers' poverty attributions are affected by their exposure to poverty in the municipality in which they carry out their activities. Based on the previous research (Blomberg et al., 2013; Lee et al., 2004), we formulate the hypothesis that the higher the level of local poverty (and thus social workers' exposure to it), the more likely social workers are to attribute poverty to structural causes and less likely to support individualistic explanations.

To analyse poverty attributions, we used survey data gathered from 600 social workers engaged in child and family welfare services in Hungary in 2019. In testing our hypotheses on the effects of social workers' exposure to poverty on their beliefs, we estimated multilevel linear regressions. Social workers' exposure to poverty, the key independent variable of our analyses, was measured using municipal-level indicators of poverty and individuallevel survey data (i.e. social workers' perceptions of local poverty).

The rest of this paper is structured as follows. In Sect. 1, we briefly outline the Hungarian context. Section 2 reviews the literature concerning the theoretical and empirical 
approaches to attributions for poverty among social workers. Section 3 discusses the data and methods used. Our results are presented in Sect. 4. Finally, Sect. 5 presents the conclusions.

\section{Poverty After the Post-Socialist Transition-The Case of Hungary}

Economic growth, following a deep recession caused by the transition crisis, enabled the post-socialist countries to catch up with the old member states of the EU in terms of income levels. However, not every social group has benefited equally from this development, which has led to widening income inequality in all countries, albeit to varying degrees. Indeed, the historical heritage and the applied economic and social policies have resulted in different development paths within the post-socialist bloc, reflected in the rate of economic growth as well as in the extent and nature of social inequalities (Medgyesi \& Tóth, 2021).

In Hungary, the catching-up is slow and happens with moderate income inequality and poverty. In recent years the rate of relative income poverty has been falling, $12.3 \%$ in 2019, which was lower than that of the EU28 countries as a whole (16.8\%). However, the income gap between the poor and the rest of society is increasing. The rate of severe material deprivation is fairly high at a national level, but is particularly high, at $26.6 \%$ in the lowest income quintile (Eurostat Database, 2020). According to some calculations, Hungary has the third highest extreme poverty ${ }^{1}$ rate in the EU when low income and severe deprivation were considered together (Bradshaw \& Movshuk, 2019). Poverty as a social problem in Hungary is therefore mainly manifested in the form of persistent marginalisation and severe material deprivation of the most vulnerable groups, whose situation has hardly changed over the past years (Branyiczki \& Gábos, 2019).

Since the political-economic transition, the main factors increasing the risk of poverty in Hungary have been the poor labour market position and low levels of education, both of which are closely related. Besides, certain groups are more exposed to the risks of poverty, such as those living in the least developed regions, villages, single-parent families, and those with many children, as well as the Roma (HCSO, 2018).

Unlike in most developed countries, where poverty and social exclusion are more prevalent in big cities (Wacquant, 2009; Rae, 2012), in post-socialist countries marginalised groups are concentrated in rural villages and small towns of the old industrial zones (Szirmai et al., 2016). This is also the case in Hungary, where the disparities between the capital and the deprived rural areas are very significant, much greater than within the capital (HCSO Database, 2020). The least developed regions face persistent poverty partly because of the structural problems in the local labour markets, and because these areas have less developed human infrastructure and uneven access to high-quality social, health, and education services (Ferge, 2010). Therefore, not only is the degree of poverty higher but also the accumulation of disadvantages is more frequent than in the more developed parts of the country.

\footnotetext{
1 Although there is no consensus on the definition, the notion of extreme poverty not only refers to being at the bottom of the income distribution hierarchy but also to a different level of well-being. The combination of very low income and severe material deprivation, which is an essential feature of extreme poverty (Bradshaw \& Movshuk, 2019), often leads to a chronic or permanent state associated with several forms of social exclusion.
} 
Several studies have addressed the marginalisation and the social and spatial exclusion of the Roma population (e.g. Kemény \& Janky, 2005; Szalai \& Zentai, 2014). The risk of poverty, especially extreme poverty, is particularly high among those whose exposure to the main risk factors is above average (Gábos \& Tóth, 2017). Although extreme poverty is not ethnically specific, the Roma are ten times more likely to fall into extreme poverty than the non-Roma population (Autonómia, 2013).

Since the conservative political turn in 2010, there has been a significant shift in social policy that is reflected in the cuts in social expenditure and a sharp turn to workfare. The expansion of the public works programme has served to provide income for those excluded from the labour market, but the low wages and precarious employment have contributed to an increase in persistent poverty rather than labour market integration (Scharle \& Szikra, 2015). Besides, increasing emphasis has been placed on various personal social services in combatting poverty and related social problems. Whereas the local authorities are responsible for the provision of most services, they are (partly or fully) financed by the central government. The number of services operating in settlements reflects the financial capacity of the local governments and their efforts to address poverty. Evidence confirms that the latter is affected by the local discourse on poverty and the perceived deservingness of potential recipients (Husz, 2018; see also Schwarcz, 2012).

Child and family welfare services have the closest contact with poor families. In one out of five cases, major issues detected by family and child welfare services were directly related to subsistence difficulties, but family conflicts, life management, and child-raising difficulties can often be associated with poverty, too (HCSO, 2016).

Since 2016, each settlement should have had a child and family service tasked with the duty of playing a supportive role by providing social assistance, information and consultancy support, coordination and skills development programmes, community development, and other prevention programmes and leisure activities. In reality, however, few settlements were able to fulfil all their regulatory obligations. Personal and material resources necessary to guarantee quality services were unevenly distributed (Husz et al., 2020). In the most disadvantaged small settlements, which suffered most from extreme poverty, services were often available only for $2-4 \mathrm{~h}$ each week, with a single person taking care of all relevant tasks (Gál, 2017). Nearly a quarter of the family and child welfare services were single-person ones (HCSO Database, 2020). In many municipalities, the staff were often busy solving crisis situations and providing social assistance, and no sufficient resources were left for prevention and development activities (Kopasz, 2017).

\section{Perceptions of the Causes of Poverty-Literature Review}

\subsection{Theoretical and Empirical Approaches}

The theoretical discourse on the causes of poverty is dominated by individualistic and structural perspectives (see e.g. Niemelä, 2008; Taylor-Gooby, 1991; van Oorschot \& Halman, 2000). The individualistic approach focuses on cultural and behavioural factors. Poverty is conceived as a result of internal factors such as inappropriate behaviour of the poor, lack of motivation, or living an indecent way of life. The structural approach focuses on external factors and emphasises the unfavourable position of the poor in the social hierarchy. In this view, poverty results from problems in society that lead, for example, to the lack of opportunity or low income. In this sense, poor people are victims of social structures. 
Feagin (1972) was the first to systematically examine-in a national sample in the US-what people believe about the causes of poverty. He developed a list of 11 potential explanations of poverty, and a priori categorised them into three groups: (1) individualistic, which attributed responsibility for poverty to the poor themselves; (2) structural, which focused on external social and economic factors; and (3) fatalistic, which accounted for factors beyond the control of individuals and society.

Several studies used Feagin's original 11 survey items with minor adjustments. Findings from factor-analytic studies generally supported Feagin's classification (e.g. Feather, 1974; Lepianka, 2007; Niemelä, 2008). At the same time, studies that significantly modified the original list produced incongruent results (e.g. Cozzarelli et al., 2001; Furnham, 1982; Morçöl, 1997).

Van Oorschot and Halman (2000) refined Feagin's classification and identified four types of poverty explanations: (i) individual blame, (ii) individual fate, (iii) social blame, and (iv) social fate. The first three types are comparable to Feagin's classification, whereas the fourth considers social factors responsible for poverty, and also deems them uncontrollable and impersonal, that is, the poor are seen as victims of broad social and economic developments, such as technological developments and recession. This classification has been employed by a number of studies using data from the Eurobarometer and other international surveys (e.g. Kainu \& Niemelä, 2014; Lepianka et al., 2010; Marquis, 2020).

\subsection{Social Workers' Perceptions of the Causes of Poverty}

Relatively few poverty attribution studies have been conducted among social workers (or certain groups within the profession) thus far (e.g. Blomberg et al., 2013; Niemelä, 2011; Weiss-Gal et al., 2009). Evidence from different countries has generally indicated that social workers (or social work students) are likely to favour structural explanations of poverty over individualistic ones. This holds true even for countries in liberal welfare regimes such as the US and Israel (Bullock, 2004; Reingold \& Liu, 2008; Weiss-Gal et al., 2009). One exception is a study in Latvia, which reported that social workers tend to explain poverty by individualistic rather than structural (and family/fatalistic) causes (Landmane \& Reņge, 2010).

Studies of social workers have mainly focused on the role of individual-level characteristics in shaping their poverty attributions. Previous findings concerning the role of gender in the formation of social workers' poverty beliefs are controversial. While Sun (2001) and Blomberg et al. (2013) found that women tend to support structural explanations of poverty more than men, Cozzarelli et al. (2001) showed few gender differences. Some research evidence is available on the effects of social work education and the amount of time spent in education on attributions for poverty. Earlier U.S. studies show that social workers with a master's degree are more willing to support structural perspectives of poverty than those with a bachelor's degree (Rehner et al., 1997; Reingold \& Liu, 2008). In a similar vein, Blomberg et al. (2013) revealed that Nordic social workers without a degree in social work are more inclined to agree with individual blame explanations and less inclined to agree with social blame explanations than are those with a degree. Not only the amount of time spent in education but also the amount of work experience in the field of social work may be related to perceptions of the causes of poverty. According to the findings of Blomberg et al. (2013), social workers with longer work experience are more likely to support social blame explanations, and less likely to support individual blame and individual fate explanations. 


\subsection{The Impact of Contextual Factors on Poverty Attributions}

Our knowledge of how and through what mechanisms contextual factors, including community- and country-level characteristics, affect beliefs about the causes of poverty is limited. There is some sporadic evidence indicating that people's explanations for the causes of poverty are shaped by the socio-economic characteristics (e.g. the level of poverty, or the political climate) of the community contexts (Hopkins, 2009; Lepianka et al., 2010). This limited body of research has been conducted among lay people.

In an influential study, Lee et al. (2004) reformulated the contact hypothesis (for review see e.g. Jackson, 1993), according to which "contact between members of an in-group and an out-group is expected to improve the attitudes of the former toward the latter by replacing in-group ignorance with first-hand knowledge that disconfirms stereotypes" (2004: 40). Lee and his colleagues switched the focus of the contact hypothesis from contact to exposure, which encompasses at least four possibilities of how the in-group can learn about the out-group (the homeless people in the study): information from third-party sources (i.e. sources other than homeless persons); direct observation of homeless people in everyday settings; interaction with homeless individuals; membership in the out-group (e.g. having homeless family members or friends). Testing the revised contact hypothesis using data from a U.S. survey, the study concluded that respondents exposed to homelessness were more likely to attribute this condition to structural causes and less likely to adhere to individual causes. Furthermore, the analyses yielded support for the contact hypothesis regardless of the type of exposure.

Drawing on the study of Lee and his colleagues (2004), Merolla et al. (2011) raised the question of whether and how community-level 'concentrated disadvantage' that is, the geographic concentration of poverty and associated social conditions-may shape people's explanations of poverty. Their starting point was that exposure by enhancing the opportunity for social contact is the key mechanism by which community contexts may influence poverty attributions. However, exposure to the poor may involve different types of contact. Research has shown that equal-status and/or intimate (as opposed to impersonal) relationships with the poor increase people's adoption of structural explanations of poverty. In contrast, impersonal or anonymous contacts with the poor enhance support for individualistic beliefs about poverty (Lee et al., 1990; Wilson, 1996). The findings of Merolla et al. (2011) revealed that people living in areas with more 'concentrated disadvantage' displayed increased support for both individualistic and structural explanations of poverty. This 'dual consciousness' (see Kluegel \& Smith, 1986; Kluegel et al., 1995) is attributed by the authors to people's greater exposure to social contact that simultaneously fosters individualistic and structural poverty beliefs.

Cross-country studies on poverty attributions usually focus on the impact of countrylevel characteristics on poverty beliefs (see e.g. da Costa \& Dias, 2015; Lepianka et al., 2010; Marquis, 2020). Da Costa and Dias (2015), utilising data from Eurobarometer 2007, reported that the most developed countries (those ranking highest in terms of the Human Development Index and with the lowest poverty rates) attributed poverty to individualistic and fatalistic causes, while the least developed countries explained it through structural causes. Drawing on data from Eurobarometer surveys, Marquis (2020) demonstrated that higher exposure to (macro-level) social and economic hardship, measured by the unemployment rate and economic growth, increases the choice of structural attributions.

The closest antecedent to our research is a cross-country study by Blomberg et al. (2013), which analysed the effect of contextual factors (including community- and 
country-level ones) on poverty attributions in a sample of social workers. They assumed that higher exposure to social problems increases the adoption of structural explanations of poverty and decreases support for individualistic explanations. The study was carried out in four Nordic countries and showed that higher exposure to poverty, measured by the local unemployment rate, is associated with increased support for structural explanations of poverty.

\section{Hypothesis, Data, and Methodology}

\subsection{Hypothesis}

Our research is based on the assumption that social workers' perceptions of the causes of poverty are not independent of the extent of poverty in their area of work. Taking into account the theoretical considerations and previous empirical findings, and also in line with Blomberg et al. (2013), our hypothesis is that social workers working in municipalities with higher levels of poverty, that is, social workers experiencing greater exposure to poverty (not only via client contact but also non-client contact, direct observation, etc.), are more likely to support structural poverty attributions and less likely to blame the poor for their poverty.

\subsection{Data}

Our empirical analysis was based on a survey of family and child welfare service workers carried out between November 2018 and February 2019. The primary goal of the data collection process was to review the working conditions of those engaged in the services and it included a block of questions on the perceptions of the causes of poverty. For sampling, we had a list of municipalities with family and child welfare services and the number of social workers in each municipality. The applied multi-stage stratified sampling method was as follows. First, a random sample of counties was taken to ensure regional representativeness. Then, the municipalities ${ }^{2}$ of the selected counties were stratified according to the number of social workers, and a random sample was taken from each strata. The aim of this procedure was to include an appropriate proportion of single-person services in the sample.

In total, 178 out of 652 municipalities and 9 out of 23 capital districts were included in the sample. In each municipality, the proportion of social workers contacted varied between 50 and $100 \%$, depending on the number of staff in the local service. A Computer-assisted personal interview (CAPI) was conducted with each social worker, with the response rate being $65 \%$. After data cleaning, the database contained 600 persons, which is $19 \%$ of the total family and child welfare worker population. The sample of social workers was predominantly female ( $90 \%$ women), and whereas $12 \%$ lived in Budapest, $52 \%$ lived in towns and $36 \%$ in small settlements. A third of the respondents were aged between 30 and 39 years, another third between 40 and 49 years, and those below 30 years and above 50 years each constituted $16 \%$ of the sample. On average, they had over 9 years of experience in social work. All of them had some type of tertiary education: nearly two-thirds had a degree in social work or a related discipline.

\footnotetext{
2 districts in the case of the capital.
} 


\subsection{Dependent Variables}

Previous studies applied two main empirical approaches to study causal attributions for poverty. Feagin (1972) used factor analysis, whereas studies adopting the four-type classification proposed by van Oorschot and Halman (2000) used a forced choice question asked in the Eurobarometer survey. Although the literature has highlighted certain weaknesses of these approaches (Lepianka, 2010; Marquis, 2020), both are used actively (cf. Hunt \& Bullock, 2016). Here, we applied the factor-analytic approach and asked for the respondents' agreement to ten statements pertaining to causal attributions for poverty (see Table 1). Most items were included in earlier research, for example, nine of our ten items were also used by Niemelä (2011). The response options were coded on a 4-point scale ranging from 'strongly agree' and 'agree' to 'disagree,' and 'strongly disagree.'

As Table 1 shows, social workers in family and child services most often attributed poverty to the lack of education and skills. As many as $84 \%$ of them agreed or strongly agreed with this statement. The majority of the respondents explained poverty with some structural factor. As many as $57 \%$ agreed that poverty is caused by the inaccessibility of social services and inadequacy of social services was also blamed by a similar fraction of respondents. Over half the respondents mentioned inequality of opportunities as well. At the same time, nearly half the respondents presented individualistic explanations of poverty: $47 \%$ agreed that the poor 'spend on things they cannot afford' and $42 \%$ agreed that laziness and lack of will power were major causes of poverty. Only a few thought that the poor can only blame themselves for their situation (19\%). According to our results, social workers in Hungary tended to agree either with structural or individualistic explanations. There is a sign of polarisation of beliefs rather than 'split consciousness' (Kluegel $\&$ Smith, 1986), that is, the simultaneous endorsement of individualistic and structuralist explanations was rare. As for fatalistic explanations, every second respondent agreed that poverty was an inevitable part of modern progress, while only a few attributed it to bad luck $(17 \%)$.

The dependent variables of the analysis have been defined with the use of exploratory factor analysis of the ten items listed in Table 1. The results suggest two underlying factors: the first was strongly and positively correlated with items describing structural explanations of poverty (lack of opportunities, injustice, inadequacy of social services and inaccessibility of social services), while the second was positively correlated with individualistic explanations and only weakly and negatively correlated with structural ones (for a summary see Table 1 and for detailed results see the Appendix, Table 4). Similarly to some other studies (e.g. Cozzarelli et al., 2001), the fatalistic explanation of poverty did not emerge as a separate factor in our analysis.

\subsection{Independent Variables}

Some of the studies analysing the effect of the local context on poverty attributions used single indicators like the unemployment rate or the percentage of recipients of social benefits to measure the extent of social problems in the municipalities (e.g. Blomberg et al., 2013), while other studies defined a composite index of local disadvantage (e.g. Merolla et al., 2011). We applied this latter approach and constructed a composite index to measure municipality-level poverty. Our starting point was the At risk of poverty or social exclusion (AROPE) indicator, the EU2020 official poverty measure, which combines indicators of 


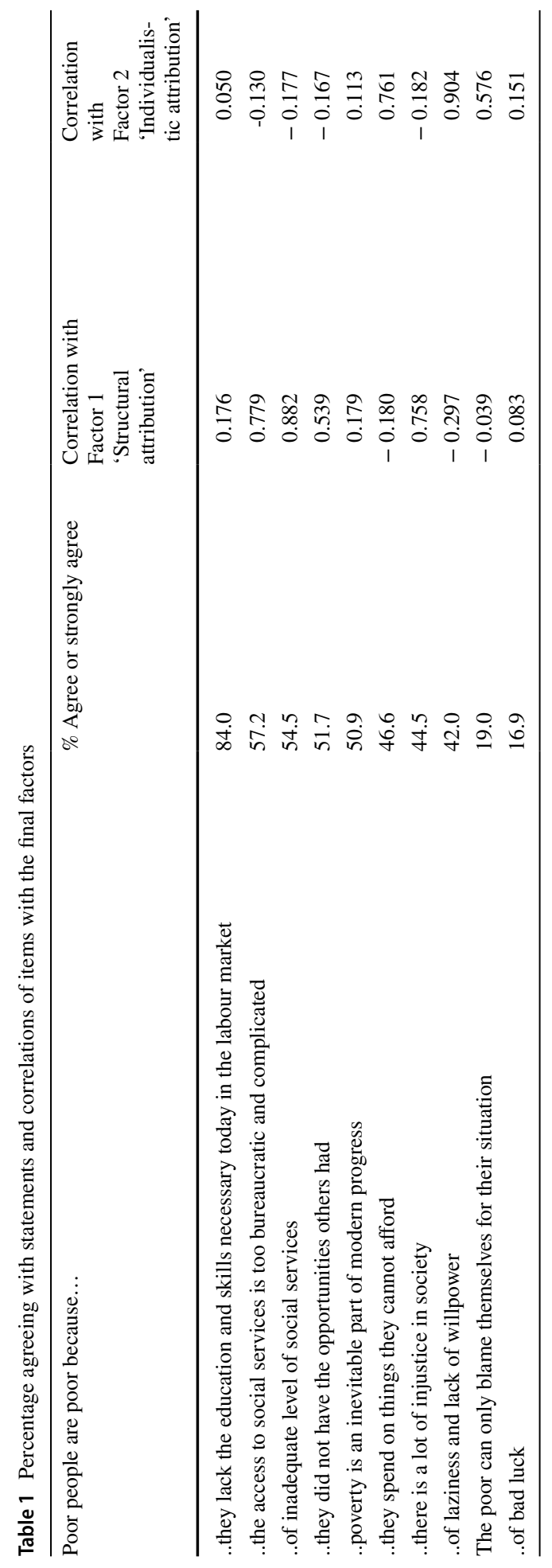


income poverty, material deprivation and labour market exclusion. We aimed to capture all three dimensions of the AROPE at the municipality level by using two indicators for each dimension.

Local level poverty is difficult to measure in Hungary, because data for territorial units below NUTS2 level are scarce. To measure the income poverty and material deprivation dimensions of poverty we relied on proxy variables. In the absence of municipality-level income poverty data, we decided to use data on recipients of means-tested benefits. Our aim was to cover all main types of means-tested benefits available in Hungary (regular child protection allowance; benefit for persons in active age/old-age allowance), thus including all broad age groups.

The percentage of recipients of regular child protection allowance ("rendszeres gyermekvédelmi kedvezmény") ${ }^{3}$ among those aged 0-17 was used as a proxy for child poverty. In Hungary, the poor of working age are entitled to benefit for persons in active age ("aktív korúak ellátása), ${ }^{4}$ and the retired poor are entitled to the old-age allowance ("idôs korúak járadéka"). ${ }^{5}$ Accordingly, the percentage of those receiving any of these two benefits was used as a proxy for adult poverty.

Data related to the items of the (severe) material deprivation rate are not available at the municipality level. Therefore, we relied on two proxy variables: the percentage of those living in substandard housing, and the percentage of children who are entitled to free meals over the holidays (for more on this benefit, see Husz, 2018). This latter provision was intended by the government to be a tool against food deprivation of children, therefore, it seemed reasonable to use this as a proxy measure of material deprivation.

The indicators related to labour market exclusion were the unemployment rate and the percentage of participants in public employment services in the municipality. The participants in public employment schemes in Hungary are mostly the long-term unemployed, particularly those with low levels of education or professional skills. Research shows that those employed in public works are not very likely to enter the open labour market (CseresGergely \& Molnár, 2015), thus participation in public works is considered as a form of labour market exclusion, in spite of the fact that those employed in public works are not counted among the officially unemployed. The definition of the six indicators used in the derivation of the composite index follows the official definition and the source of data is the Hungarian Central Statistical Office (HCSO). The distribution of the indicators among all Hungarian municipalities is shown in the Table 5 of the Appendix.

We used principal component analysis, performed on all municipalities in Hungary, to derive a composite index of municipality-level poverty based on the six indicators outlined above. This is one of the standard procedures for weighting and aggregation of the indicators into a single index (Booysen, 2002; Greco et al., 2019; OECD, 2008). The principal component analysis resulted in one extracted component, which explained $73 \%$ of the total

\footnotetext{
3 The regular child protection allowance is given to children living in households where per capita monthly income is below approx. $€ 127$ in 2019.

4 A person is eligible for the benefit for persons in active age if the family's monthly income per consumption unit does not exceed $90 \%$ of the minimum old-age pension, which is approx. €79 in 2019.

5 Old-age allowance is given to persons who are of legal retirement age and are living with a spouse or cohabiting partner, if the per capita income, including the income of the spouse, is not higher than €79 in 2019. The income threshold is higher among persons living alone: $€ 93$ below the age of 75 , and $€ 125$ if age is equal to or higher than 75 .
} 
variance (see details in Table 6 in the Appendix). This composite index of poverty was used as the main independent variable in our basic regression analyses. ${ }^{6}$

Our analysis controlled for a number of variables that may have affected the respondents' opinions about the causes of poverty, including age cohort (a dummy variable to identify those who were born before 1968 and thus became adults during the socialist period), the amount of social work experience, presence of a social work or related degree (sociology or social policy), ${ }^{7}$ and childhood experience of hardship (a dummy variable denoting whether the respondent had experienced poverty or other related problems in childhood).

Further control variables were also included as proxies for social service quality: two dummy variables indicating single-person services and whether the respondent received supervision in the preceding year, and a variable measuring the presence of job stress (those who cannot spend enough time with their clients are assumed to suffer job stress, see Blomberg et al., 2015). Another group of control variables captured the municipality's characteristics. Also, we controlled for the settlement type (capital, towns, and villages). The number of social services available in the settlement was included in the model to measure the municipality's effort to mitigate poverty. Descriptive statistics of the variables used in the analysis are shown in Table 7 of the Appendix.

\subsection{Methods}

We used multilevel linear regression models with random intercepts at the municipality level to test our hypothesis. After running our basic regression models we conducted further analysis of the relationship between local poverty and causal attributions of poverty by examining non-linear effects and using alternative indicators of local poverty and exposure to poverty.

\section{Results}

The results of the multilevel models show that the acceptance of individualistic poverty explanations is associated with our composite index of municipal-level poverty even after controlling for individual and municipal-level control variables (see Table 2, Model 1). The regression coefficient is positive, meaning that higher values of the poverty index are associated with stronger acceptance of individualistic attributions to poverty. In the case of the structural explanations of poverty, our analysis failed to detect a statistically significant effect of exposure to poverty. The regression coefficient is negative, but its value is low and not statistically different from zero (see Table 2, Model 2). Overall, these findings do not support the hypothesis that the acceptance of structural explanations increases and

\footnotetext{
6 The construction of a composite index requires us to make several decisions about the selection, scaling, weighting and aggregation of the indicators used (e.g. Booysen, 2002). These decisions involve a considerable amount of subjectivity. In order to address this issue, we perform sensitivity analysis using some other versions of the index.

7 Hungarian child and family workers are required by the law to have at least a bachelor's degree in social sciences, so the only differences are in the type of social science studies (e.g. social work, sociology, social pedagogy, mental hygiene, etc.). Since child and family workers are a homogeneous group in terms of educational background, it is assumed that there are no significant differences in their level of knowledge about poverty.
} 
Table 2 Baseline multilevel regression models of poverty explanations

\begin{tabular}{|c|c|c|c|c|}
\hline & \multicolumn{2}{|c|}{$\begin{array}{l}\text { Model } 1 \\
\text { Individualistic explanations }\end{array}$} & \multicolumn{2}{|l|}{$\begin{array}{l}\text { Model } 2 \\
\text { Structural } \\
\text { explanations }\end{array}$} \\
\hline \multicolumn{5}{|l|}{ Individual-level control variables } \\
\hline Born before 1968 & $-0.26 * *$ & $(2.96)$ & 0.14 & $(1.52)$ \\
\hline Experience of social work (years) & 0.01 & $(1.52)$ & 0.00 & $(0.47)$ \\
\hline Having social work degree & $-0.14^{*}$ & $(2.12)$ & $0.18^{*}$ & $(2.46)$ \\
\hline Childhood experience of hardship & -0.11 & $(1.63)$ & 0.07 & $(0.96)$ \\
\hline One-person social service & 0.10 & $(1.03)$ & 0.03 & $(0.33)$ \\
\hline Supervision attendance & 0.05 & $(0.60)$ & 0.10 & $(1.21)$ \\
\hline Job stress & 0.06 & $(0.08)$ & $0.24 * *$ & $(3.28)$ \\
\hline No. of local social services & $0.05^{* *}$ & $(2.67)$ & $-0.05^{*}$ & $(2.54)$ \\
\hline \multicolumn{5}{|l|}{ Municipal-level variables } \\
\hline \multicolumn{5}{|l|}{ Settlement type } \\
\hline \multicolumn{5}{|l|}{ Capital (reference) } \\
\hline Town & $0.89 * * *$ & $(4.40)$ & -0.46 & $(1.96)$ \\
\hline Village & $0.10 * * *$ & $(4.61)$ & $-0.70 * *$ & $(2.78)$ \\
\hline Municipal-level poverty (composite index) & $0.16^{*}$ & $(2.50)$ & -0.02 & $(0.31)$ \\
\hline Constant & $-1.05^{* * *}$ & $(4.10)$ & 0.47 & $(1.60)$ \\
\hline \multicolumn{5}{|l|}{ Random-effects parameters } \\
\hline Municipality-level intercept variance & $1.19 * * *$ & & $0.28 * * *$ & \\
\hline Individual-level variance & $0.42 * * *$ & & $0.47 * * *$ & \\
\hline Log likelihood & -611.4 & & -653.6 & \\
\hline$N$ & 549 & & 549 & \\
\hline Number of groups (municipalities) & 184 & & 184 & \\
\hline
\end{tabular}

z-values in parenthesis, ${ }^{*} p<0.05, * * p<0.01, * * * p<0.001$

the acceptance of individualistic explanations declines when social workers are exposed to higher levels of poverty in the municipality where they work. We performed sensitivity analysis using other variants of the composite index of municipality-level poverty, and the main results remained basically unchanged (results available upon request).

In addition, our statistical analysis shows that individual-level and municipal-level control variables also have a significant effect on the causal attributions for poverty. Those who were born before 1968 and became adults during the socialist period were less inclined to attribute poverty to individual factors. This result is in line with our expectation about the effect of egalitarian ideology of the socialist era on poverty attributions. Education is also a key factor in social workers' explanations for poverty. Those with social work or other related tertiary degree have a significantly higher acceptance of structural explanations and significantly lower acceptance of individualistic explanations for poverty. Somewhat surprisingly, experience in social work does not affect explanations of poverty. Social workers who were overburdened and could not spend enough time with their clients tended to attribute poverty more to structural reasons. In settlements where poverty mitigation efforts were higher (measured by the higher number of available social services), the acceptance of structural explanations was lower and respondents were more likely to blame the poor for their situation. Compared to social workers in Budapest, respondents in towns and 
Table 3 Further multilevel models of individualistic poverty explanations

\begin{tabular}{|c|c|c|c|c|c|c|}
\hline & \multicolumn{2}{|c|}{$\begin{array}{l}\text { Model } 3 \\
\text { Individualistic } \\
\text { explanations }\end{array}$} & \multicolumn{2}{|c|}{$\begin{array}{l}\text { Model } 4 \\
\text { Individualistic } \\
\text { explanations }\end{array}$} & \multicolumn{2}{|c|}{$\begin{array}{l}\text { Model } 5 \\
\text { Individualistic } \\
\text { explanations }\end{array}$} \\
\hline \multicolumn{7}{|l|}{ Municipal-level poverty (composite index) } \\
\hline Lowest quartile & Ref. & & & & & \\
\hline Lower middle quartile & 0.01 & $(0.06)$ & & & & \\
\hline Upper middle quartile & 0.18 & $(1.33)$ & & & & \\
\hline Highest quartile & $0.38 * *$ & $(2.58)$ & & & & \\
\hline \multicolumn{7}{|l|}{ Spatial concentration of poverty } \\
\hline Above-median value on 0 indicator & & & ref. & & Ref. & \\
\hline Above-median value on 1 or 2 indicators & & & -0.09 & $(0.66)$ & -0.11 & $(0.85)$ \\
\hline Above-median value on 3 or 4 indicators & & & -0.01 & $(0.04)$ & -0.07 & $(0.50)$ \\
\hline Above-median value on 5 or 6 indicators & & & $0.42 * *$ & $(3.26)$ & $0.34^{*}$ & $(2.57)$ \\
\hline \multicolumn{7}{|l|}{ Subjective measure of exposure to povery } \\
\hline $\begin{array}{l}\text { Agree: many Roma families in the area } \\
\text { (dummy) }\end{array}$ & & & & & -0.05 & $(0.55)$ \\
\hline $\begin{array}{l}\text { Agree: many families in extreme poverty } \\
\text { (dummy) }\end{array}$ & & & & & $0.22 *$ & $(2.51)$ \\
\hline Control variables & Yes & & Yes & & yes & \\
\hline Constant & $-1.23 * * *$ & $(4.86)$ & $-1.20 * * *$ & $(4.89)$ & $-1.31 * * *$ & $(5.37)$ \\
\hline \multicolumn{7}{|l|}{ Random effects parameters } \\
\hline Municipality-level intercept variance & 0.19 & & 0.17 & & 0.16 & \\
\hline Individual-level variance & 0.42 & & 0.42 & & 0.42 & \\
\hline Log-likelihood & -610.0 & & -606.3 & & -603.0 & \\
\hline $\mathrm{N}$ & 549 & & 549 & & 549 & \\
\hline Number of groups (municipalities) & 184 & & 184 & & 184 & \\
\hline
\end{tabular}

Z-values in parenthesis, $* p<0.05, * * p<0.01, * * * p<0.001$. Models were estimated with the same control variables as included in models of Table 2

villages are more likely to attribute poverty to individual causes and less likely to adhere to structural causes.

\subsection{Further Analyses}

As discussed above, the results of our baseline regression model do not confirm our hypothesis regarding the effect of local poverty on causal attributions for poverty. To better understand the relationship between local poverty and causal attributions among social workers we conducted further analyses (see results in Table 3). First, in order to detect non-linear effects of local poverty, we introduced in the model a categorical version of the composite index of municipal-level poverty, using the quartiles of the variable. Then we analysed the relationship using alternative measures of local poverty. First, we defined a measure of spatial concentration of poverty using the same six poverty indicators described above. This measure counts the number of indicators on which the municipality has an above-median value. This variable thus identifies municipalities where the different aspects of poverty tend to occur simultaneously and are characterised by concentrated disadvantage. A four-category version of the variable was used in the regression models, with 
values 0: below-median values on all six indicators, 1: above-median values on one or two indicators, 2: above-median values on three or four indicators, 3: above- median values on five or six indicators.

In addition, a subjective measure of exposure to poverty was also included in the model. This measure is based on a survey question that asked the respondents whether their area of service provision was characterised by the presence of many families living in extreme poverty (included in the model as a dummy variable 1-strongly agree or agree, 0-disagree, strongly disagree). A similar survey question asked the respondents whether they agree that many Roma families live in their work area. This question was used to analyse whether causal attributions for poverty are influenced by feelings about the Roma minority.

These variables were included in the multilevel regression models with the same control variables as before. Results regarding the determinants of individualistic poverty attributions are shown in Table 3 (results for control variables are not shown but are similar to the results in Table 2), while results for structural explanations of poverty are shown in Table 9 in the Appendix. Results of this further analysis confirm that local poverty is positively associated with the acceptance of individualistic explanations of poverty, while is not related to structural explanations of poverty. These new results also add further important insights regarding the impact of the local poverty context.

As shown in Model 3 of Table 3., the relationship between the categorical version of the already used composite poverty index and individualistic attribution for poverty displays a nonlinear pattern. Social workers blame the poor for their poverty only in the poorest municipalities, while moderate poverty does not lead to such opinions. When looking at the impact of the variable measuring spatial concentration of poverty, this non-linear pattern becomes even more striking (see Table 3, Model 4). The agreement with individualistic explanations of poverty is higher only in municipalities characterised by a high concentration of disadvantage, having relatively high values on most ( 5 or 6 ) indicators. At the same time, respondents in municipalities having above-median values on fewer indicators are not different from those working in settlements where all poverty indicators are low.

Findings using the subjective measure of exposure to poverty are also consistent with our previous results. Social workers who have experienced high levels of extreme poverty around them were more likely to agree with individualistic explanations for poverty than those with different perceptions. It is worth mentioning that the results do not indicate anti-Roma sentiments among social workers. A higher perceived rate of Roma families in the area of work did not influence social workers' poverty attributions when all other variables were controlled for (see Table 3, Model 5). We note that the results regarding the spatial concentration of poverty remain unchanged if the subjective measure of exposure to poverty is also included in the model.

Overall, these results suggest that it is not poverty in general that leads to a higher acceptance of individualistic explanations of poverty among Hungarian social workers, but the presence of high levels of multiple deprivation and exposure to extreme poverty.

\section{Conclusions and Discussion}

This study investigated social workers' poverty explanations in Hungary, a post-socialist country in which extreme poverty is among the highest in the EU. We expected that social workers' thinking about poverty is affected by their exposure to poverty in the municipality in which they carry out their activities. Our hypothesis was that social workers experiencing greater exposure to poverty are more likely to support structural poverty attributions and less likely to blame the poor 
for their poverty. We tested our hypothesis using data from a survey conducted among child and family welfare workers in Hungary.

Our results show that most social workers, in daily interaction with poor families, explained poverty with structural causes in Hungary. However, individual blame was also frequent (similar to the lay population). We pointed out that these contradictory opinions were not simultaneously present in the respondents' minds. Structural and individual causes were typical in separate groups with different characteristics. These findings challenge the idea that the split consciousness theory developed for public perceptions could also be applied to social service professionals.

The results show that the hypothesised negative relationship between exposure to poverty and individualistic poverty attributions does not hold in general. Social workers working in the most disadvantaged municipalities have a higher tendency to accept individualistic explanations of poverty. Using a subjective indicator of poverty, we obtained similar results: acceptance of individualistic explanations is higher among those who perceive more extreme poverty in their area of social provision.

This result is consistent with some of the findings in the literature (e.g. Merolla et al., 2011) which suggest that exposure to concentrated disadvantage may increase acceptance of individual causes for poverty. One possible explanation is that severe poverty may lead to more frequent occurrences of behavioural patterns that are considered irrational or deviant, which may seem like deficiencies in character even in the eyes of a family and child welfare worker, especially if he/she has a degree other than social work (or related fields). High-quality training, supervision, and other types of regular professional support can help social workers cope with these difficulties.

Further investigation is necessary to explore how social workers' daily interactions with (extremely) poor people are affected by their perceptions of the causes of poverty. Poor families are largely dependent on child and family welfare workers who are responsible for delivering anti-poverty assistance to them. Individual blame may result in less supportive behaviour towards them and less active search for solutions to their problems. If so, in the most deprived settlements of Hungary, social workers' perceptions may also contribute to the development of multiple disadvantages.

Despite growing interest, we still do not know enough about the consequences of high spatial concentration of (extreme) poverty. Our study draws attention to the fact that this may also affect the attitude of institutional actors towards the poor. Further research is needed to understand the mechanisms behind this. But this would require appropriate indicators and adequate data collection. The EU statistical system, for example, has excellent indicators for measuring the extent and depth of poverty, whereas the data and measurement tools needed to map the spatial concentration of disadvantages are lacking. Efforts should be made to improve the poverty indicator system in this direction. 


\section{Appendix 1}

\section{Exploratory Factor Analysis for the Creation of the Dependent Variables}

Exploratory factor analysis has been carried out on the set of ten items related to individual poverty attributions (see Table 4). There are four factors that have positive eigenvalues but the scree-plot suggests a two-factor solution (see Figure 1). For easier interpretation of results, factors were rotated with oblique (oblimin) rotation in order to allow for correlation between the factors. The first factor obtained after rotation is strongly and positively correlated with items describing structural explanations of poverty (lack of opportunity, bad luck, inadequacy and inaccessibility of social services). The second factor extracted is positively correlated with individualistic explanations of poverty, while only weakly and negatively correlated with structural explanations (see Table 4). After exploring the factor structure of the ten items it became clear that items c) ("bad luck") and i) ("poverty is inevitable part of modern progress") are not emerging as a separate factor representing the „fate" dimension of poverty attributions identified in the literature. ${ }^{8}$ In addition, it became also clear that these items together with item h) ("lack of education and skills") are not strongly correlated with any of the two factors emerging from the analysis. Therefore, the factor scores that were finally used in the analysis as dependent variables are result of a second factor analysis where these three items were omitted.

See Fig. 1.

See Tables 4, 5, 6, 7, 8, 9.

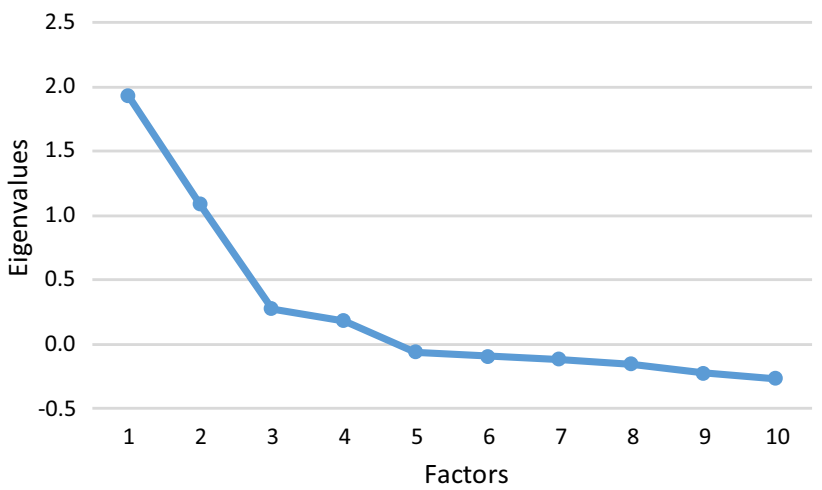

Fig. 1 Scree plot from exploratory factor analysis of 10 items

\footnotetext{
${ }^{8}$ Item (i) ,poverty is inevitable part of modern progress" is most closely related to Factor 3, but this factor is also correlated to some of the items considered to be part of structural explanations. Item c) „bad luck” is most closely correlated with Factor 4, but again it is difficult to propose a clear-cut interpretation of this factor.
} 
Table 4 Rotated factor loadings from exploratory factor analysis of 10 items

\begin{tabular}{|c|c|c|c|c|}
\hline Variable: The poor are poor beacuse... & Factor1 & Factor2 & Factor3 & Factor4 \\
\hline (a)..they spend on things that they cannot afford & 0.017 & 0.625 & -0.041 & -0.086 \\
\hline (b).. of laziness and lack of willpower & -0.077 & 0.656 & -0.014 & -0.011 \\
\hline (c)..of bad luck & 0.035 & 0.113 & 0.179 & 0.322 \\
\hline (d)..they didn't have the opportunities others had & 0.190 & -0.185 & 0.438 & 0.002 \\
\hline (e)..there is a lot of injustice in our society & 0.460 & -0.139 & 0.305 & 0.109 \\
\hline (f)..of inadequate level of social services & 0.758 & -0.006 & -0.052 & -0.007 \\
\hline $\begin{array}{l}\text { (g)..the access to social services is too bureaucratic and compli- } \\
\text { cated }\end{array}$ & 0.699 & 0.035 & -0.040 & -0.037 \\
\hline $\begin{array}{l}\text { (h)..they lack the education and skills that are necessary today on } \\
\text { the labour market }\end{array}$ & 0.079 & 0.065 & 0.212 & -0.325 \\
\hline (i)..poverty is inevitable part of modern progress & -0.020 & 0.076 & 0.419 & -0.005 \\
\hline (j) The poor can only blame themselves for their situation & 0.040 & 0.465 & 0.086 & 0.165 \\
\hline
\end{tabular}

Factors were extracted with principle factors method, only factors with positive eigenvalues shown. Rotation method used: oblique oblimin

Table 5 The distribution of the six municipal-level poverty indicators among all Hungarian municipalities

\begin{tabular}{lccrrr}
\hline & $\begin{array}{l}\text { Mean } \\
(\%)\end{array}$ & 25th percentile (\%) & $\begin{array}{l}\text { Median } \\
(\%)\end{array}$ & $\begin{array}{l}\text { 75th } \\
\text { percentile } \\
(\%)\end{array}$ & N \\
\hline \% Receiving child protection allowance & 25.4 & 6.1 & 17.9 & 39.8 & 3177 \\
\% Receiving social benefits & 2.4 & 0.5 & 1.3 & 3.1 & 3177 \\
Unemployment rate (\%) & 5.6 & 2.5 & 4.3 & 7.5 & 3177 \\
\% In public employment service & 4.1 & 0.7 & 2.2 & 5.5 & 3177 \\
\% In substandard housing & 14.9 & 6.8 & 12.5 & 20.4 & 3177 \\
\% Receiving free school meals & 15.7 & 0.0 & 5.9 & 23.6 & 3177 \\
Composite index of poverty & 0.000 & -0.748 & -0.321 & 0.449 & 3177 \\
\hline
\end{tabular}

Table 6 Results of principal component analysis over six poverty indicators $(N=3177)$

\begin{tabular}{lllll}
\hline & Eigenvalue & Difference & Proportion & Cumulative \\
\hline 1st component & 4.348 & 3.706 & 0.725 & 0.725 \\
2nd component & 0.642 & 0.178 & 0.107 & 0.832 \\
3rd component & 0.464 & 0.196 & 0.077 & 0.909 \\
4th component & 0.268 & 0.116 & 0.045 & 0.954 \\
5th component & 0.151 & 0.023 & 0.025 & 0.979 \\
6th component & 0.128 & & 0.021 & 1.000 \\
\hline
\end{tabular}


Table 7 Descriptive statistics of variables included in the baseline multilevel models

\begin{tabular}{lccccc}
\hline Variable & Obs & Mean & SD & Min & Max \\
\hline Individualistic explanations of poverty & 549 & 0.006 & 0.844 & -1.597 & 1.895 \\
Structural explanations of poverty & 549 & 0.016 & 0.884 & -1.911 & 1.822 \\
Cohort (born before 1968) & 549 & 0.186 & 0.389 & 0 & 1 \\
Experience of social work & 549 & 9.473 & 8.298 & 0 & 44 \\
Social work diploma & 549 & 0.627 & 0.484 & 0 & 1 \\
Childhood experience of problems & 549 & 0.392 & 0.489 & 0 & 1 \\
One-person service & 549 & 0.253 & 0.435 & 0 & 1 \\
Participated in supervisory meeting & 549 & 0.388 & 0.488 & 0 & 1 \\
Cannot spend enough time with clients & 549 & 0.659 & 0.474 & 0 & 1 \\
No. of social services available in town & 549 & 6.555 & 3.368 & 0 & 12 \\
Budapest & 549 & 0.117 & 0.321 & 0 & 1 \\
Town & 549 & 0.515 & 0.500 & 0 & 1 \\
Village & 549 & 0.368 & 0.483 & 0 & 1 \\
Municipal-level poverty (composite index) & 549 & -0.426 & 0.716 & -1.067 & 2.605 \\
\hline
\end{tabular}




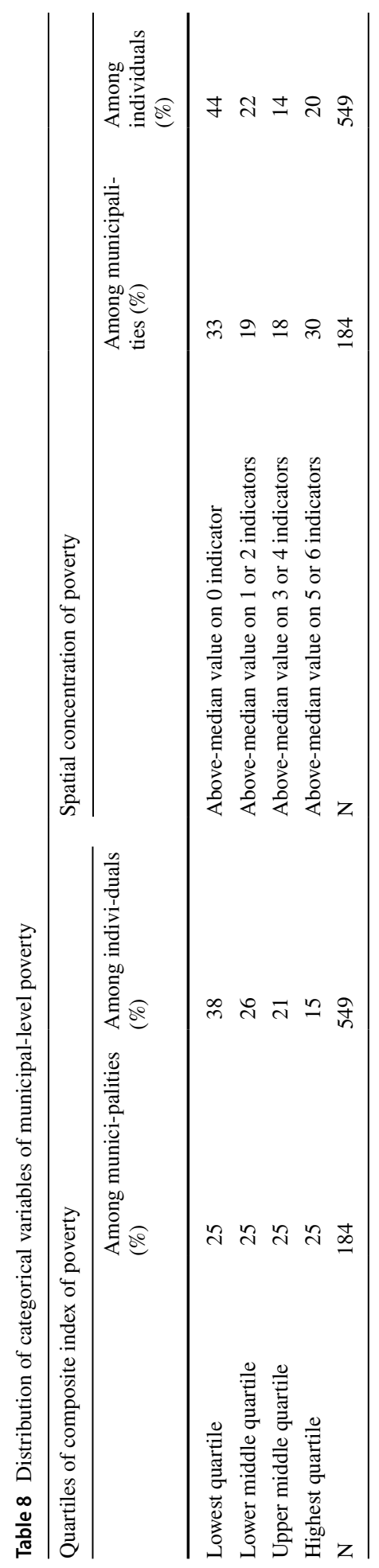


Table 9 Further multilevel models of structural poverty explanations

$\begin{array}{lll}\text { Model 3 } & \text { Model 4 } & \text { Model 5 } \\ \text { Structural } & \text { Structural } & \text { Structural } \\ \text { explanation } & \text { explanation } & \text { explanation }\end{array}$

Municipal-level poverty (composite index)

Lowest quartile

Lower middle quartile

Upper middle quartile

Highest quartile

Spatial concentration of poverty

Above-median value on 0 indicator

Above-median value on 1 or 2 indicators

Above-median value on 3 or 4 indicators

Above-median value on 5 or 6 indicators

Subjective measure of exposure to povery

Agree: many Roma families in the area (dummy)

Agree: many families in extreme poverty (dummy)

Control variables

Constant

Random effects parameters

Municipality-level intercept variance

Individual-level variance

Log-likelihood

$\mathrm{N}$

Number of groups (municipalities)
Ref.

$-0.03 \quad(0.20)$

$-0.01 \quad(0.08)$

$-0.16 \quad(0.93)$

Z-values in parenthesis, ${ }^{*} p<0.05, * * p<0.01, * * * p<0.001$

Models were estimated with the same control variables as included in models of Table 3

Acknowledgements We thank Péter Róbert and Tamás Barczikay for their helpful comments on earlier versions of the study.

Funding Open access funding provided by Centre for Social Sciences. This study was supported by the "Professional Support for Integrated Child Opportunities Programmes (HRDOP-1.4.1-15)" and the Mobility Research Center at the Centre for Social Sciences, Hungary (Cooperation of Excellences Programme of the Hungarian Academy of Sciences).

Data Availability Survey data available upon request.

Code Availability Statistical software code available upon request.

\section{Declarations}

Conflicts of interest The authors have no conflicts of interest to declare that are relevant to the content of this article.

Ethical Approval This manuscript has not been published and is not under consideration for publication elsewhere. The study was conducted in accordance with the international, national, and institutional ethical standards of the Centre for Social Sciences/local institution. 
Consent for Publication My colleagues, Ildikó Husz, Marianna Kopasz and I conducted the research and co-authored the manuscript. All of us have approved the manuscript for submission to Social Indicators Research, and I am the corresponding author.

Open Access This article is licensed under a Creative Commons Attribution 4.0 International License, which permits use, sharing, adaptation, distribution and reproduction in any medium or format, as long as you give appropriate credit to the original author(s) and the source, provide a link to the Creative Commons licence, and indicate if changes were made. The images or other third party material in this article are included in the article's Creative Commons licence, unless indicated otherwise in a credit line to the material. If material is not included in the article's Creative Commons licence and your intended use is not permitted by statutory regulation or exceeds the permitted use, you will need to obtain permission directly from the copyright holder. To view a copy of this licence, visit http://creativecommons.org/licenses/by/4.0/.

\section{References}

Autonómia (2013). A mélyszegénységben élők helyzete Magyarország legszegényebb kistérségeiben. Budapest: Autonómia Alapítvány. Retrieved October 31, 2019, from http://www.melyszegenyseg.hu/dokum entumok/dokumentumtar_tartalma/TAMOP\%20513\%20kutatas_1kor_Zarotanulmany.pdf

Blomberg, H., Kroll, C., Kallio, J., \& Erola, J. (2013). Social workers' perceptions of the causes of poverty in the Nordic countries. Journal of European Social Policy, 23(1), 68-82. https://doi.org/10.1177/ 0958928712456575

Blomberg, H., Kallio, J., Kroll, C., \& Saarinen, A. (2015). Job stress among social workers: Determinants and attitude effects in the Nordic countries. British Journal of Social Work, 45(7), 2089-2105. https:// doi.org/10.1093/bjsw/bcu038

Booysen, F. (2002). An Overview and Evaluation of Composite Indices of Development. Social Indicators Research, 59, 115-151. https://doi.org/10.1023/A:1016275505152

Bradshaw, J., \& Movshuk, O. (2019). Measures of extreme poverty applied in the European Union. In H. P. Gaisbauer, G. Schweiger, \& C. Sedmak (Eds.), Absolute poverty in Europe: Interdisciplinary perspectives on a hidden phenomenon (pp. 39-72). Policy Press.

Branyiczki, R. \& Gábos, A. (2019). Poverty dynamics during the economic crisis in Hungary. In I. Gy. Tóth (Ed), Hungarian Social Report 2019 (pp. 176-194). TÁRKI

Bullock, H. E. (2004). From the Front Lines of Welfare Reform: An Analysis of Social Worker and Welfare Recipient Attitudes. Journal of Social Psychology, 144(6), 571-588. https://doi.org/10.3200/SOCP. 144.6.571-590

Cozzarelli, C., Wilkinson, A. V., \& Tagler, M. J. (2001). Attitudes Toward the Poor and Attributions for Poverty. Journal of Social Issues, 57(2), 207-227. https://doi.org/10.1111/0022-4537.00209

Cseres-Gergely, Zs., \& Molnár, Gy. (2015). Labour market situation following exit from public works". In K. Fazekas \& J. Varga (Eds.), The Hungarian Labour Market, 2015 (pp. 148-159). Institute of Economics.

Da Costa, L. P., \& Dias, J. G. (2015). What do Europeans Believe to be the Causes of Poverty? A Multilevel Analysis of Heterogeneity Within and Between Countries. Social Indicators Research, 122(1), 1-20. https://doi.org/10.1007/s11205-014-0672-0

Eurostat Database (2020). Tables ilc_li02 and ilc_mddd13. Retrieved August 8, 2020 from http://ec.europa. eu/eurostat/data/database

Feagin, J. R. (1972). Poverty: We still believe that God helps those who help themselves. Psychology Today, $6,101-129$.

Feather, N. T. (1974). Explanations of poverty in Australian and American samples: The person, society, or fate? Australian Journal of Psychology, 26(3), 199-216. https://doi.org/10.1080/00049537408255231

Ferge, Zs. (2010). Key specificities of the social fabric under new-capitalism. Corvinus Journal of Sociology and Social Policy, 1(2), 3-28.

Furnham, A. (1982). Why are the poor always with us? Explanations for poverty in Britain. British Journal of Social Psychology, 21(4), 311-322. https://doi.org/10.1111/j.2044-8309.1982.tb00553.x

Gábos, A., \& Tóth, I. G. (2017). Recession, Recovery, and Regime Change: Effects on Child Poverty in Hungary. In B. Cantillon, Y. Chzhen, S. Handa, \& B. Nolan (Eds.), Children of Austerity: Impact of the Great Recession on Child Poverty in Rich Countries (pp. 118-145). Oxford University Press. 
Greco, S., Ishizaka, A., Tasiou, M., et al. (2019). On the Methodological Framework of Composite Indices: A Review of the Issues of Weighting, Aggregation, and Robustness. Social Indicators Research, 141, 61-94. https://doi.org/10.1007/s11205-017-1832-9

Gál, A. (2017). Gondolatok a 20 éves gyermekjóléti szolgáltatásról. In Z. L. Lakner, E. Gulyásné Kovács \& L. Csókay (Eds.), „Nem csak szív kell, de tudás is!” 20 éves a Gyermekvédelmi Törvény. (pp.76-98). SZOSZAK

HCSO (2016). Gyermekesély - A gyermekvédelmi jelzőrendszer múködése, 2014. Retrieved August 25, 2020, from https://www.ksh.hu/docs/hun/xftp/stattukor/gyermekvedelem14.pdf

HCSO (2018). A háztartások életszínvonala, 2018. Retrieved August 8, 2020, from https://www.ksh.hu/ docs/hun/xftp/idoszaki/hazteletszinv/2018/index.html\#section-14

HCSO Database (2020). Dissemination Database of Hungarian Central Statistical Office. Retrieved July 10, 2020 from http://statinfo.ksh.hu/Statinfo/themeSelector.jsp?\&lang=en

Hopkins, D. J. (2009). Partisan Reinforcement and the Poor: The Impact of Context on Explanations for Poverty. Social Science Quarterly, 90(3), 744-764. https://doi.org/10.1111/j.1540-6237.2009.00641.x

Hunt, M., \& Bullock, B. (2016). Ideologies and Beliefs About Poverty. In D. Brady \& L. M. Burton (Eds.), The Oxford Handbook of the Social Science of Poverty (pp. 93-116). Oxford University Press.

Husz, I. (2018). 'You Would Eat If You Were Hungry' Local Perceptions and Interpretations of Child Food Poverty. Children \&amp; Society, 32(3), 233-243.

Husz, I., Kopasz, M., \& Rácz, A. (2020). A szegénységben élő gyermekes családok társadalmi mobilitásának esélyei a családsegítő szakemberek szemszögéből. Esély, 31(4), 32-53.

Jackson, J. W. (1993). Contact Theory of Intergroup Hostility: A Review and Evaluation of the Theoretical and Empirical Literature. International Journal of Group Tensions, 23(1), 43-65.

Kainu, M. \& Niemelä, M. (2014). Attributions for Poverty in Post-Socialist Countries. Retrieved July 20, 2020, from http://muuankarski.github.io/attributions/article2013.pdf

Keiser, L. R. (1999). State Bureaucratic Discretion and the Administration of Social Welfare Programs: The Case of Social Security Disability. Journal of Public Administration Research and Theory, 9(1), 87-106. https://doi.org/10.1093/oxfordjournals.jpart.a024407

Kemény, I. \& Janky, B. (2005). Roma population of Hungary 1971-2003 In I. Kemény (Ed) Roma of Hungary. (pp. 70-225). East European Monographs, CO - Atlantic Research and Publications

Kluegel, J. R. \& Smith, E. R. (1986). Beliefs about inequality: Americans' views of what is and what ought to be. Aldine de Gruyter.

Kluegel, J. R., Csepeli, Gy., Kolosi, T., Örkény, A., \& Neményi, M. (1995). Accounting for the Rich and the Poor: Existential Justice in Comparative Perspective. In J. R. Klugel, D. Mason, \& B. Wegener (Eds.), Social justice and Political Change: Public Opinion in Capitalist and Post-communist States (pp. 179-207). Aldine de Gruyter.

Kopasz, M. (2017). A családsegítő és gyermekjóléti szolgáltatás integrációjának és az ellátórendszer kétszintúvé történő átalakításának tapasztalatai. TÁRKI. Retrieved September 17, 2020, from https:// www.tarki.hu/hu/news/2017/kitekint/20170425_csaladsegito.pdf

Landmane, D., \& Reṇge, V. (2010). Attributions for Poverty, Attitudes Toward the Poor and Identification with the Poor Among Social Workers and Poor People. Baltic Journal of Psychology, 11(1-2), 37-50.

Lee, B. A., Jones, S. H., \& Lewis, D. W. (1990). Public Beliefs about the Causes of Homelessness. Social Forces, 69(1), 253-265. https://doi.org/10.1093/sf/69.1.253

Lee, B. A., Farrell, C. R., \& Link, B. G. (2004). Revisiting the Contact Hypothesis: The Case of Public Exposure to Homelessness. American Sociological Review, 69(1), 40-63. https://doi.org/10.1177/ 000312240406900104

Lepianka, D. (2007). Are the Poor to be Blamed or Pitied? A Comparative Study of Popular Poverty Attributions in Europe. PhD Thesis, Tilburg University, NL.

Lepianka, D., Gelissen, J., \& van Oorschot, W. (2010). Popular Explanations of Poverty in Europe: Effects of Contextual and Individual Characteristics across 28 European Countries. Acta Sociologica, 53(1), 53-72. https://doi.org/10.1177/0001699309357842

Lipsky, M. (1980). Street-level bureaucracy. Dilemmas of the individual in public services.

Marquis, L. (2020). Lay explanations for poverty: A multilevel analysis of European public opinion (19762014). In R. Careja, P. Emmenegger, \& N. Giger (Eds.), The European Social Model under Pressure (pp. 253-275). Springer VS.

Medgyesi, M., \& Tóth, I. G. (2021). Income, wealth, employment, and beyond: Central and eastern Europe. In G. Fischer \& R. Strauss (Eds.), Europe's income, wealth, consumption, and inequality (pp. 177217). Oxford University Press. https://doi.org/10.1093/oso/9780197545706.003.0005.

Merolla, D. M., Hunt, M. O., \& Serpe, R. T. (2011). Concentrated Disadvantage and Beliefs about the Causes of Poverty: A Multi-Level Analysis. Sociological Perspectives, 54(2), 205-227. https://doi.org/ 10.1525/sop.2011.54.2.205 
Meyers, M. K., \& Vorsanger, S. (2003). Street-level bureaucrats and the implementation of public policy. In B. G. Peters \& J. Pierre (Eds.), Handbook of Public Administration (pp. 245-254). Sage.

Morçöl, G. (1997). Lay explanations for poverty in Turkey and their determinants. Journal of Social Psychology, 137(6), 728-738. https://doi.org/10.1080/00224549709595494

Niemelä, M. (2008). Perceptions of the Causes of Poverty in Finland. Acta Sociologica, 51(1), $23-40$.

Niemelä, M. (2011). Public and Social Security Officials' Attributions of Poverty in Finland. European Journal of Social Security, 13(3), 351-371. https://doi.org/10.1177/138826271101300303

Rae, A. (2012). Spatially concentrated deprivation in England: An empirical assessment. Regional Studies, 46(9), 1183-1199. https://doi.org/10.1080/00343404.2011.565321.

Rehner, T., Ishee, J., Salloum, M., \& Velasues, D. (1997). Mississippi Social Workers' Attitudes toward Poverty and the Poor. Journal of Social Work Education, 33(1), 131-142. https://doi.org/10.1080/ 10437797.1997.10778858

Reingold, D., \& Liu, H. (2008). Do Poverty Attitudes of Social Service Agency Directors Influence Organizational Behavior? Nonprofit and Voluntary Sector Quarterly, 38(2), 307-332. https://doi.org/10.1177/ 0899764008316967

Scharle, Á. \& Szikra, D. (2015). Recent Changes Moving Hungary Away from the European Social Model. In D. Vaughan-Whitehead (Ed.), The European Social Model in Crisis. Is Europe Losing Its Soul? (pp. 229-261). Edward Elgar

Schwarcz, Gy. (2012). Ethnicizing poverty through social security provision in rural Hungary. Journal of Rural Studies, 28, 99-107. https://doi.org/10.1016/j.jrurstud.2012.01.022.

Sun, A. P. (2001). Perceptions among Social Work and Non-Social Work Students Concerning Causes of Poverty. Journal of Social Work Education, 37(1), 161-173. https://doi.org/10.1080/10437797.2001. 10779044

Szalai, J. \& Zentai, V. (Eds.), (2014) Faces and causes of Roma marginalization in local contexts. Hungary, Romania, Serbia. CPS CEU

Szirmai, V., Schuchmann, J., \& Halász, L. (2016). Posztszocialista jóllét és területi egyenlőtlenség a Kárpátmedencében. Tér és Társadalom, 30(4), 110-128. https://doi.org/10.17649/TET.30.4.2838.

Taylor-Gooby, P. (1991). Social Change. University of Toronto Press.

OECD (2008). Handbook on Constructing Composite Indicators. Methodology and User Guide. OECD, European Commission JRC, OECD Paris.

van Oorschot, W., \& Halman, L. (2000). Blame or Fate, Individual or Social? An International Comparison of Popular Explanations of Poverty. European Societies, 2(1), 1-28. https://doi.org/10.1080/14616 6900360701

Wacquant, L. (2009). Punishing the Poor. The Neoliberal Government of Social Insecurity. Duke University Press

Weiss-Gal, I., Benyamini, Y., Ginzburg, K., Savaya, R., \& Peled, E. (2009). Social Workers' and Service Users' Causal Attributions for Poverty. Social Work, 54(2), 125-133. https://doi.org/10.1093/sw/54.2. 125

Wilson, G. (1996). Toward a Revised Framework for Examining Beliefs about the Causes of Poverty. The Sociological Quarterly, 37(3), 413-428. https://doi.org/10.1111/j.1533-8525.1996.tb00746.x

Publisher's Note Springer Nature remains neutral with regard to jurisdictional claims in published maps and institutional affiliations. 